\title{
Longing to Belong: Needing to be Needed in a World in Need
}

\section{Young Perspectives}

\author{
Shirley Le Penne ${ }^{1}$
}

Published online: 24 October 2017

(C) Springer Science+Business Media, LLC 2017

\begin{abstract}
"No one in this desert, neither he nor his guest, mattered. And yet, outside this desert neither of them (...) could have really lived." Albert Camus, The Guest
\end{abstract}

Representing both plentiness and emptiness, the desert reflects Millennials' infinite field of choices and possibilities, as well as the fragility of their content. In modern societies, "communitiness," or sensing belonging to a social group, is not exclusive anymore: people can opt to identify with any number of different communities, rather than one that they are born into. By choosing to join these communities, individuals fulfil their longing to belong, a basic human need according to Maslow. Yet, it appears that for Millennials, nominally joining a community does not automatically mean belonging to it. And not having that strong sense of belonging often compensates itself in feeling obliged to personally impact the world.

Social belonging, according to Maslow, is inherent to the human condition and nature. The lack of it might lead to various undesirable effects, such as decreased health, unhappiness or maladjustment (Baumeister and Leary 1995). I hold that Millennials' experience of belonging raises two key questions. First, in an age where the community you are born into is often not the community you later adhere to, where groups are often virtual, and interpersonal relations mediated online, what does belonging mean? Second, is belonging experienced as a duty to be fulfilled?

Modern society has shaped the art of making people feel dispensable (Junger 2016). Millennials understand belonging

Shirley Le Penne

shirleylepenne@gmail.com

1 Department of Political Science, Tel Aviv University, Tel Aviv, Israel to a community as an opportunity to reverse this tendency: pursuing a sense of belonging becomes a means of achieving a sense of being needed. It is not only about joining a community, but about developing a deep understanding of the community's needs in order to achieve them for its sake, out of care and empathy. Within communitiness, the feeling of being needed creates a sense of indispensability, worthiness, self-respect and autonomy in individual's self-perception. A recent survey shows that $80 \%$ of Millennials are active in a community outside of work, illustrating that the willingness and appropriateness of contributing allows one to develop a deep sense of solidarity to the community, thus boosting one's personal blossoming (Perlis 2017).

Millennials experience belonging by seeking to impact the world. Acknowledging both the world's fragility and their own ephemerality, Millennials understand the world needs saving, and needs to be changed. And for it to happen, the world needs them. Yet, instead of belonging to the world, passively, they realize that the world belongs to them, as an available platform waiting to be used and on which they must mark their footprints. 'Create an impact' has become a mantra for members of Generation Y, almost perceived as a personal duty. Its non-realization is endured as a deep failure and potentially puts personal identity's construction at stake.

Fulfilling the need to be needed and affecting a world in need, paves the path to the next steps in Maslow's hierarchy of needs. However, it seems that an essential element constituting belonging remains to be addressed, and that is the sense of mutuality. Here, community is not the end, but a means to achieve other ends, to move one level up the hierarchy: when we contribute to our community assuming that we would be gratified by it, one gives only to receive. What then happens when the feeling that "the community needs me", turns into "I need the community"? Shall we remember that outside the desert, neither of $u s$ could really live? 


\section{Further Reading}

Baumeister R. F. \& Leary M. R. 1995. The Need to Belong: Desire for Interpersonal Attachments as a Fundamental Human Motivation. Psychological Bulletin, Vol. 117, No. 3, 497-529.

Junger S. 2016. Tribe: On Homecoming and Belonging. New York: Twelve. Maslow, A. H. 1968. Toward a psychology of being. New York: Van Nostrand.
Perlis, M. 2017. What do millennials want from life? Huffington Post, June 03, 2017. http://www.huffingtonpost.com/mike-perlis/whatdo-millennials-want-_b_10257926.html

Shirley Le Penne is an MA student, a research assistant and a teaching assistant in Political Science at Tel Aviv University, specializing in Political Philosophy and International Relations. She completed her BA in Political Science and History of the Middle East. 